\title{
VALUING PUBLIC TRANSPORTATION USING CONTINGENT VALUATION METHOD: A STUDY OF COMMUTER LINE (KRL) IN TANGERANG SELATAN, WEST JAVA INDONESIA
}

\author{
Endah Saptutyningsih*, Laila Karimah
}

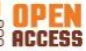

\section{AFFILIATION:}

Universitas Muhammadiyah Yogyakarta. Indonesia.

\section{*CORRESPONDENCE:}

endahsaptuty@umy.ac.id

THIS ARTICLE IS AVALILABLE IN:

http://journal.umy.ac.id/index.php/esp

DOI: 10.18196/jesp.20.1.5017

\section{CITATION:}

Saptutyningsih, E. \& Karimah, L. (2019). Valuing Public Transportation Using Contingent Valuation Method: A Study of Commuter Line (KRL) in Tangerang Selatan, West Java Indonesia. Jurnal Ekonomi \& Studi Pembangunan, 20(1), 89-98

\section{ARTICLE HISTORY}

Received:

October 2018

\section{Accepted:}

April 2019
Abstract: This study aims to determine the value of willingness to pay for commuter line (KRL) users to improve the quality of KRL services and identify determinants of willingness to pay for KRL service users to improve service quality. The method used in this study is a contingent valuation method. In collecting data used the face to face interview method with the Electric Rail Train user. The results of the study show that the average WTP for improving the quality of KRL services is IDR 4,500 (USD 0.32). The cleanliness, comfort, travel time, and income of each KRL user affect the KTP users to improve the quality of KRL services. The result of the study is expected to improve the quality of KRL services, especially in South Tangerang, and can be a reference for managers for public transportation services.

Keywords: Public Transportation; Willingness To Pay, Contingent Valuation Method; Commuter Line; Economic Valuation.

JEL Classification: R40.

\section{Introduction}

The use of electric train services or known as KRL can be the main choice in transportation services. Therefore, rail transportation services must be able to provide maximum satisfaction to users, especially in terms of service and convenience of customers on the train. Logit models have been used in several previous studies to examine the determinants of service quality of different modes of transportation (Hensher, 2002; Henser, 2001). By using this model, various determinants of the quality of transportation service services can be estimated.

One of the most widely used means of transportation is the commuter line (KRL). In 2015 the use of KRL train services increased by $40.65 \%$. The total number of passengers is $257,530,195$ for all Jabodetabek KRL users with 705,562 passengers per day, the number of stations passed by KRL per day is 881,70 stations and there are $666 \mathrm{KRL}$ units used. Net income received by Jabodetabek Commuter PT. KAI is IDR1.7 trillion with a total number of employees of 3,028 people. Safety for the users of this service is continually improved so that people feel comfortable when entrain, PT. KAI installed as 
many as 300 CCTVs that were distributed throughout the stations and train cars (PT KAl's report, 2017).

Tangerang is a business city that competes with the capital city of Jakarta which has the highest level of mobility. The high population density and the high value of land in Tangerang as a business center are highly dependent on surrounding areas such as Jakarta, Bogor, and Bekasi in their economic activities. High mobility from the buffer zone to the center and vice versa, requires effective and efficient transportation and the right type of transportation. The number of KRL Commuter Line passengers in November 2016 was around 24,104 people or 4.75 percent of the total number of train passengers outside Java and in December 2016 it increased to 24841 people. From January to February 2017 it was noted that there was a decrease in the number of Jabodetabek KRL passengers to 21,743 people. In March 2017 it increased to 25,411 passengers. This figure continues to increase until May 2017 as 27,385 passengers and down again in June, which is around 24,432 . In July 2017 the number of passengers rose to 27,016 passengers and continued to increase along with access to work locations which was getting easier and faster when using KRL.

Based on the PT KAI Report (2017) there are several shortcomings of PT. KAI include: 1) Number of passengers who always exceed capacity so that it is not comfortable; 2) Disruption of facilities and infrastructure as well as technical problems so that the departure and arrival schedules are often not on time; 3) Train accidents often occur either caused by human errors or technical errors so that they cannot provide safe services. Therefore, it is necessary to improve the quality of KRL services so that users get satisfaction.

The satisfaction of KRL users to obtain good services can be measured using economic valuations. User satisfaction is one item that has no market price or in other words nonmarket goods. To conduct an economic valuation of non-market goods can be determined by calculating the amount of willingness to pay (WTP). Willingness to Pay (WTP) is the willingness to pay for a better quality of goods and services. This study aims to calculate PAPs for KRL service users to improve the quality of KRL services and the factors that influence them.

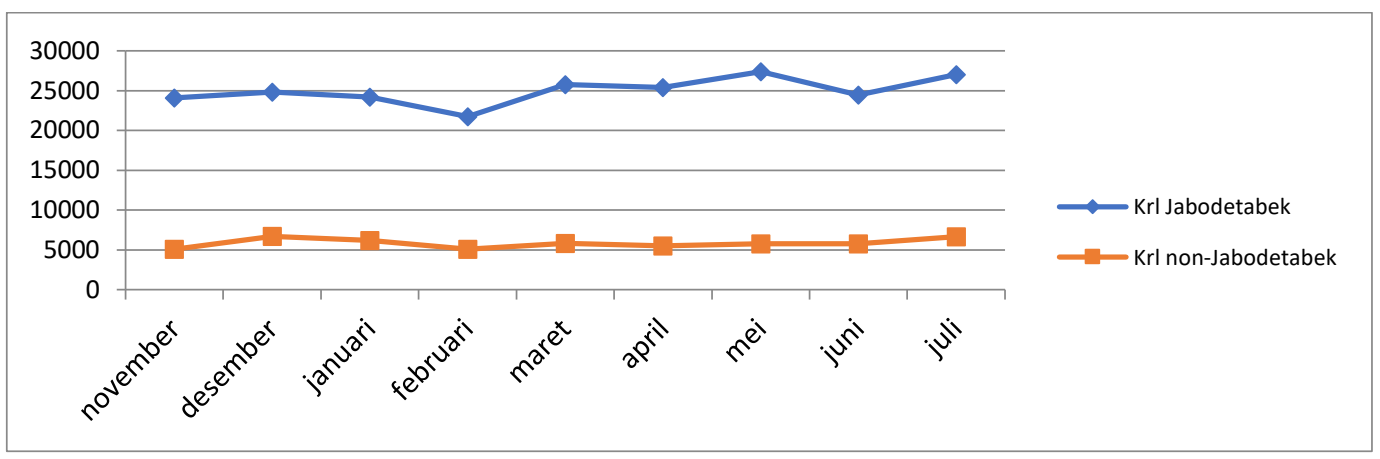

Figure 1 The number of passengers of KRL Source: Central Statistics Agency, 2017 
This study is similar to the study conducted by Sari and Setiartiti (2015) with CVM analysis tools. The average WTP to improve the quality of trains is IDR 78,666 per person. The study found that age, length of education, income, number of dependents, the purpose of the trip had a positive and significant effect on long-distance economy class trains in Jogja-Jakarta. The study conducted by Lestari and Nahdalina (2017) found that the ease of buying tickets, cleanliness, security and service personnel had a positive and significant influence on PAPs. The users of Kopaja bus services are willing to pay an additional more than IDR2000 for service to increase.

Emalia and Huntar (2015) use CVM with binary logistic regression analysis. The study found that income and education level had a positive and significant effect on PAPs while the frequency of garbage transportation had a positive but not significant effect on PAPs. The total number of PAPs for service quality is IDR 18,200. As many as 73 respondents were willing to pay for waste processing and comply with processing rules while as many as 21 respondents did not comply with the rules. Permata (2012) found that airport trains were made to facilitate access to the airport with an average WTP of Rp 23,195. The percentage of respondents who want to pay for safety services to be better is $80 \%$. As many as $50 \%$ of respondents stated that the most dominant priority in customer service for railroad users was the timeliness of service. While respondents who stated that convenience needs to be prioritized as much as $20 \%$ and the rest stated that the ease of obtaining service and responsibility was necessary for serving train users. Julien and Mahalli (2015) have examined the Ability to Pay and Willingness to Pay for the Airport Railink Service. The results show that the average respondent's ability to pay is IDR 78,375 and the average willingness of the respondent to pay is IDR 60,375. However, after an increase in quality, the average respondent's ability to pay will be IDR 71,375 with the average WTP added by the respondents of IDR 22,632. Abuhamoud et al. (2011) employed binary logit analysis with the dependent variable " 0 " if using a government bus and "1" if using a car. The study was conducted in the Tripoli which has a very high level of private and public transportation use. The number of samples is 350 respondents which are stratified sampling. The study recommends reducing car use during rush hour, focus on increasing the cost of use and providing faster and more reliable public transportation.

The use of CVM in economic valuation of public transportation, especially in big cities in Indonesia, which is much in demand by public transportation users, still needs to be explored further. Therefore, this study aims to find out the determinants of WTP of KRL users for improving the quality of KRL services. It is hoped that this study can improve the quality of public transportation facilities, especially KRL in major cities in Indonesia, and the quality of transportation facilities in general so that people use more public transportation facilities rather than private vehicles. This can be one solution to reduce the high level of congestion which can also indirectly improve air quality in major cities in Indonesia.

Table 1 Relation between independent and dependent variables

\begin{tabular}{lcl}
\multicolumn{1}{c}{ Variable } & Sign & \multicolumn{1}{c}{ References } \\
\hline CLEAN & + & Lestari dan Nahdalia (2017), Masrun et al (2016) \\
COMFORT & - & Masrun et al (2016) \\
TRAVELTIME & + & Hensher dan Rose (2007), Lestari dan Nahdalia (2017) \\
INCOME & + & $\begin{array}{l}\text { Setiartiti dan Sari (2015), Emalia \& Huntar (2015), Hensher dan } \\
\text { Rose (2007) }\end{array}$ \\
\hline
\end{tabular}

Source: author calculation 


\section{Research Method}

\section{Study Site}

This study was conducted in the City of South Tangerang, precisely at stations spread in the Serpong area. The research subjects were the users of Serpong-Tanah Abang Electric Rail (KRL) services. Data is obtained directly from respondents using the on-site questionnaire technique with KRL service users who are in the area around Serpong and well informed about the facilities of the KRL.

\section{Sampling Technique}

The sampling method used for this study is a random sampling technique. According to Issac and Michael (1981), the number of samples is determined as follows:

$$
\mathrm{S}=\frac{\lambda^{2} \cdot N \cdot P \cdot Q}{d^{2}(N-1)+\lambda^{2} P Q}
$$

Where $S$ is the number of samples; $N$ is total population; $\lambda^{2}$ is chi-square, with an error rate of $10 \%$; $d$ is $0.05 ; P=Q=0.05$ so that the total sample of this study was 267 respondents.

\section{Survey design and administration}

We surveyed the KRL users in the study site to investigate their contribution to improving the KRL services quality. Their contribution was measured they willing or not to support for improving the KRL services quality by the ticket payment. These identified the KRL users who care or not about public transportation quality. In order to identify the amount of ticket price for the KRL service. We conducted a focus group discussion with $20 \mathrm{KRL}$ users who well informed about the KRL services. In the discussion, we employed the contingent valuation method that constructed a hypothetical market to measure KRL users' willingness to pay (WTP) for a certain change in the quality (Bedate, Herrero, \& Sanz, 2004; Sanz, Herrero \& A. M. Bedate, 2003). The average WTP of informed KRL users were IDR 4,500 (USD 0.32). It could distinguish visitors with sufficient financial support for the museum from those without. Based on this estimation, we designed a question to find out whether participants would be willing or not willing to pay IDR 4,500 (USD 0.32). for the KRL ticket price.

\section{Data analysis}

The researcher applied a single dichotomous choice method tied to two possible respondent answers namely "yes" or "no". The dichotomous choice method best uses the Contingent Valuation Method (CVM) approach because this method is closest to market behavior when consumers will choose to buy something or not at a certain price (Bateman et.al., 2002). We employed a logistic regression (Wang \& Elhag, 2007) to identify the determinants of KRL users' WTP for improving the quality of the KRL services. The dependent variable of the model was the KRL users' WTP for improving the quality of the 
KRL services, where 1 indicated their agreements (they willing to pay as IDR 4,500) and 0 showed their disagreements (they are not willing to pay as IDR 4,500). The independent variables of the model included cleanliness, comfort, travel time, and income.

According to Hosmer and Lemeshow (1989) binary logistic regression is an analytical method used to determine the relationship between the response variable $(y)$ and the binding variable $(x)$ which has the properties of dichotomous or polytomous. Based on empirical studies the regression models in this study are as follows:

$$
\log \left(\frac{0}{1-p}\right)=\beta_{0}+\beta_{1} \text { clean }+\beta_{2} \text { comfort }+\beta_{3} \text { travel time }+\beta_{4} \text { income }+e
$$

\section{The Characteristics of Respondents}

This study uses primary data obtained from the on-site questionnaire to 267 respondents who are KRL transportation service users, especially those departing from Serpong and Buntu Swamp stations. This study begins on January 18, 2018, until January 31, 2018.

The majority of male KRL users use KRL transportation across Jabodetabek with a percentage reaching 64.04 percent while women reach 35.96 percent. The most dominant number of family dependents 5 people, namely 25.47 percent and the least dependents are one person and the most dependents are as many as 9 people with a percentage of 1.12 percent. The most dominant type of work of respondents is as Civil Servants (PNS) as much as 68.54 percent, traders as much as 10.86 percent, students as much as 7.49 percent, entrepreneurs as much as 4.12 percent, private employees as much as 3.75 percent, teachers as many as 2, 25 percent. While housewives and CPNS as much as 0.75 percent and therapists. unemployment. TNI / Polri and professionals 0.37 percent, respectively. Age of respondents varies from 21 years to 55 years. The dominant respondents in this study were ages 21 to 25 years, which were 29.96 percent and the rarest were those aged 51 to 55 years 2.25 percent.

Respondents in this study were people who had activities in the Serpong area to Tanahabang Station. The number of family dependents is indirectly one of the characteristics of the community in using the Electric Rail (KRL). Especially for some families who have more than 3 dependents. this is one of the reasons why people make the decision to use KRL. In addition to the very cheap price, it can save monthly fees. KRL can also save travel time because there is no need to experience congestion. There are 135 respondents or 51 percent who think the number of dependents is not the main reason for using KRL. one reason for using transportation. Based on the observations of researchers on the choice in using transportation with the number of family dependents it is not the main reason for respondents to drive. this is because it is not the family's responsibility which is their reason for using KRL. However, there are other reasons for their choice of using KRL transportation.

The average income per month is one of the factors that influence the decision of KRL users in issuing costs to improve the quality of KRL services. The highest amount of income is dominated by the amount of income of IDR 2,000,000 to IDR 300,000 163 respondents 
(61 percent). 63 respondents with a percentage of 25 percent had an income of IDR 500,000 to IDR $1,000,000$ and the least amount of income was between IDR 3,000,000 to IDR 4,000,000 as many as 7 people (3 percent).

Cleanliness of transportation facilities is one of the people's choices in choosing transportation equipment. If the conditions of transportation equipment, especially clean trains, people tend to choose clean and easy trains because it will be different if they use other means of transportation such as public buses between cities and public transportation. As many as 212 respondents (79 percent) stated that the condition of the KRL was in accordance with the standard, namely the presence of a janitor. There were 55 respondents (21 percent) who thought that the current KRL conditions were not satisfactory.

Respondents' characteristics of train convenience in their journey are one of the main choices of the community. PT KAI also continues to improve the quality of its services in terms of convenience so that the community continues to use public transportation, one of which is inter-city trains provided by the government. A total of 203 respondents (76 percent) reached more than half of the respondents who agreed with company policies that would make trains with the second tier. This is known when conducting interviews with the company that they are studying this so that people can feel comfortable and not crammed in on the train again. And as many as 64 respondents ( 24 percent) who think that they do not agree with making a second-tier train because it will make it difficult for the community to go upstairs and it will be difficult when getting off the train.

Travel duration is one reason for using KRL. This is because using KRL across Jabodetabek can save time compared to using other public transportation or even using private vehicles. 247 respondents (93 percent) agreed that the length of the trip was their reason when using KRL. because it can save time to reach destinations, especially for residents of South Tangerang who have busy activities in the Jakarta area. Depok. Bekasi and Bogor. 20 respondents ( 7 percent) did not make the length of the trip as a reason for them to use KRL.

The average WTP for improving KRL service quality is IDR 4,500 obtained from focus group discussions with 15 random KRL service users by asking their WTP to improve the quality of KRL services. The minimum value of their WTP is IDR 4,000 while the maximum value is IDR 100,000 . Then it was obtained as many as 211 respondents (79 percent) were willing to pay IDR 4,500 through the ticket price of KRL from Serpong to Tanah Abang.

Table 2 WTP of respondents

\begin{tabular}{cc}
\hline WTP $=$ IDR 4,500 & Percentage \\
\hline Yes & $79 \%$ \\
No & $21 \%$ \\
Total & $100 \%$ \\
\hline
\end{tabular}

Source: author calculation 


\section{Result and Discussion}

All variables used in this study are valid based on the results of validity testing. Based on the results of the Cronbach Alpha test of the 4 variables tested in this study showed a value of -3.2 meaning that all instrument variables in this study did not have moderate reliability.

Of the 267 respondents, the majority stated that cleanliness was in accordance with their standards. Likewise, they stated that the convenience of KRL was the respondent's choice to continue using KRL. The average travel time is 21.70 minutes. The average respondent's income is IDR $2,192,883$. The average value for the willingness to pay variable is 0.79 , which indicates that the willingness to pay variable is dominated by respondents who are willing to pay IDR 4,500 to improve the quality of KRL services.

Regression feasibility test (Wald test) seen from the value of Hosmer and Lemeshow's test shows that the variables of cleanliness, comfort, length of travel, and income can provide an explanation and prediction of the value of willingness to pay. This research model is suitable for use in this study. Model fit test functions to assess whether the model is fit or not fit between the model and the data obtained. In this study, the value of -2 Log Likelihood (block $=0$ ) was 274,267 and the value of -2 Log Likelihood (block $=1$ ) was 180,979 . The decrease in value from $-2 \mathrm{LL}$ (block $=1$ ) and $-2 \mathrm{LL}$ (block $=1$ ) is 274,267 $185,008=93,228$. So it can be concluded that this study fulfills the model fit assumptions. Based on the Chi-square value in this study it can be concluded that the variables of cleanliness, comfort, length of trip and income simultaneously affect the dependent variable or at least one independent variable that affects the dependent variable.

Table 3 Descriptive Statistics of Variable

\begin{tabular}{lllll} 
& Minimum & Maximum & Mean & Std. Dev. \\
\hline CLEAN & 0 & 1 & 0,79 & 0,405 \\
COMFORT & 0 & 1 & 0,76 & 0,428 \\
\hline TRAVELTIME & 2 & 155 & 21,70 & 16,077 \\
\hline INCOME & 500000 & 4000000 & 2192883,90 & 914207,984 \\
WTP & 0 & 1 & 0,79 & 0,408 \\
\hline
\end{tabular}

Source: author calculation

Table 4 Regression result

\begin{tabular}{lccc}
\multicolumn{1}{c}{ Variable } & Coef. & Sig. & Odd ratio \\
\hline CLEAN & 3,444 & 0,000 & 31,301 \\
COMFORT & 1,170 & 0,008 & 3,223 \\
TRAVELTIME & $-0,023$ & 0,021 & 0,977 \\
INCOME & 0,000 & 0,018 & 1,000 \\
Constant & $-2,412$ & 0,002 & 0,090 \\
\hline
\end{tabular}

Source: author calculation 
The positive relationship between cleanliness and WTP variables in this study shows that KRL users who consider KRL cleanliness guaranteed to pay higher than KRL users who think that KRL cleanliness is not maintained. This shows the high concern of KRL users for the cleanliness of public transportation because they want to pay more so that the cleanliness of public transportation is maintained. The results of this study are supported by studies conducted by Lestari and Nahdalia (2017) and Masrun et al (2016).

The comfort coefficient value is positive indicating that if the KRL comfort level using KRL is high, the willingness to pay KRL users for service quality will be even higher. The positive relationship between comfort and WTP in this study is because someone wants to sacrifice more to get satisfaction by feeling more comfortable using public transportation than private vehicles. This can be made possible because using public transportation can reduce congestion and pollution. The results of this study, differ from studies conducted by Masrun et al (2016).

The duration of the trip has a significant influence on the WTP to improve the quality of $K R L$ services. The coefficient value of the variable duration of the trip is negative, indicating that visitors who take longer trips using KRL are willing to pay for improvements in the quality of KRL services. The negative relationship between the duration of the trip with the WTP in this study is because KRL users do not want to spend more money to get facilities that are not what they want. Time is one of the costs when someone does an activity. If in carrying out activities or going to a place requires longer time, then the opportunity cost will be even greater. A rational person does not want to carry out activities with high opportunity costs. Therefore, WTP KRL service users are low if the travel time is long. The results of this study, supported studies conducted by Hensher and Rose (2007), Lestari and Nahdalia (2017).

KRL service user revenue has a significant influence on the value of PAPs to improve the quality of KRL services. A positive sign indicates that KRL users who have a higher income will be willing to pay to improve the quality of KRL services. The positive relationship between income and WTP in this study is because it shows that the increasing income of KRL users will pay higher ticket prices so that better KRL services. When someone wants to get higher satisfaction, then he wants the results of this study, to have a similarity of studies conducted by Sari and Setiartiti (2015), Emalia and Huntari (2015), Hensher and Rose (2007).

\section{Conclusion}

The percentage of KRL service users who are willing to pay IDR 4,500 to improve the quality of KRL services is 79 percent. This indicates that the awareness of KRL users to improve the quality of KRL services is still low. The positive relationship between cleanliness and comfort with the WTP shows the tendency of KRL users to be willing to pay more if the quality of KRL services is improved. Users of public transportation mean transportation will tend to demand that the quality of $K R L$ services be better if the price of KRL tickets is higher. 
The results of studies that show that KRL users with higher incomes are willing to pay more to improve the quality of KRL services, indicating that KRL managers need to make market segmentation for high-income KRL users so that they can contribute in improving the quality of KRL services. Moreover, they are dominated by private vehicle users who contribute to congestion and pollution in big cities. By improving the quality of KRL services, it can reduce the level of congestion and pollution problems that can indirectly have an impact on the declining air quality and public health in urban areas. In addition, the local and central government should also reorganize urban spatial planning, and provide various modes of public transportation to limit the use of private vehicles. Future research is better to use economic valuation with various components of public transportation services and provide a variety of public transportation policy scenarios so that it can be used as a policy recommendation for public and government transport managers to encourage the use of public transportation. This is intended to reduce the level of congestion and pollution that is already quite high, especially in big cities in Indonesia.

\section{References}

Abuhamoud, M. A. A., Rahmat, R. A. O. K., \& Ismail, A. (2011). Modeling of Transport Mode In Libya: A Binary Logit Model For Government Transportation Encouragement. Australian Journal of Basic And Applied Sciences, 5(5), 1291-1296.

Bateman, I., Hanemann, M., Hanley, N., Hett, T., Jones-Lee, M., Loomes, G., Carson, R., \& Day, B. (2002). Economic Valuation with Stated Preference Techniques: A Manual. Ecological Economics. https://doi.org/10.4337/9781781009727

Bedate, A., Herrero, L.C. \& Sanz, J.A. (2004). Economic Valuation of the cultural heritage: Application to four case studies in Spain. Journal of Cultural Heritage, 5(1), 101-111. https://doi.org/10.1016/i.culher.2003.04.002

Emalia, Z., \& Huntari, D. (2015). Willingness to Pay Masyarakat Terhadap Penggunaan Jasa Pengolahan Sampah. Jurnal Ekonomi Kuantitatif Terapan, 9(1).

Hensher, D. A. (2002). A service quality index for area-wide contract performance assessment regime. Journal of Transport Economics and Policy, 18, 259-276. https://doi.org/10.1016/S0739-8859(06)18014-2

Hensher, D. A., \& Rose, J. M. (2007). Development of Commuter and Non-Commuter Mode Choice Models for The Assessment of New Public Transport Infrastructure Projects: A Case Study. Transportation Research Part A: Policy and Practice, 41(5), 428-443. https://doi.org/10.1016/j.tra.2006.09.006

Hensher, D.A. (2001). Service quality as a package: what does it mean to heterogeneous consumers?. Proceedings of 9th World Conference on Transport Research, 22-27 July, Seoul, Korea.

Hosmer, D. W., \& Lemeshow, S. (1989). Applied Regression Analysis. New York: John Willey. Retrieved from: http://Resource.Heartonline.Cn/20150528/1 3koqstg.Pdf

Julien, J., \& Mahalli, K. (2015). Analisis Ability to Pay dan Willingness to Pay Pengguna Jasa Kereta Api Bandara Kualanamu (Airport Railink Service). Ekonomi Dan Kenangan (2).

Lestari, N. A., \& Nahdalia, N. (2017). Analisis Ketersediaan Pengguna Jasa Dalam Membayar Terhadap Peningkatan Kualitas Pelayanan (Studi Kasus: Kopaja P20 Jurusan SenenLebak Bulus). Jurnal Ilmiah Desain dan Konstruksi, 16(1). 
Masrun, M., Ruslan, M., Mahyudin, I., \& Rizali, A. (2016). Analisis Penerapan Konsep EcoAirport Dengan Menggunakan Metode Willingness to Pay di Bandar Udara Syamsudin Noor Banjarmasin Kalimantan Selatan. Enviroscienteae 12(3), 247-255. https://doi.org/10.20527/es.v12i3.2450

Permata, M.R. (2012). Analisa Ability to Pay Dan Willingness to Pay Pengguna Jasa Kereta Api Bandara Soekarno Hatta-Manggarai. Thesis. Jakarta: Universitas Indonesia.

Sanz J. Á., L. C. Herrero \& A. M. Bedate. (2003). Contingent valuation and semiparametric methods: A case study of the National Museum of Sculpture in Valladolid, Spain, Journal of Cultural Economics, 27(34), 241-257. https://doi.org/10.1023/a:1026353218280

Sari, H. P., \& Setiartiti, L. (2015). Willingness to Pay Perbaikan Kualitas Pelayanan Kereta Api. Jurnal Ekonomi \& Studi Pembangunan, 16(2), 200-209.

Wang, Y., \& Elhag, T. (2007). A Comparison of Neural Network, Evidential Reasoning and Multiple Regression Analysis in Modeling Bridge Risks. Expert Systems with Applications, 32(2), 336-348. https://doi.org/10.1016/i.eswa.2005.11.029 